\title{
Monitasoinen samankaltaisuus: virolaiset ja suomenkielisen tekstin ymmärtäminen
}

\author{
PIRKKO MUIKKU-WERNER \\ Itä-Suomen yliopisto
}

Tiivistelmä. Vironkielistä tekstiä lukevien suomalaisten on havaittu hyödyntävän monenlaisia strategioita selvittääkseen sukukielen sanojen merkityksiä. Tässä artikkelissa kuvaan, millaiset seikat vaikuttavat virolaisten kykyyn ymmärtää suomea. Ulkoisen samankaltaisuuden tiedetään edistävän ymmärtämistä, mutta se voi johtaa myös virhetulkintoihin ns. riskisanojen vuoksi. Toisaalta tiettyjen käsitteiden semanttinen yhteenkuuluvuus saattaa myötävaikuttaa onnistuneen käännöksen syntymiseen. Kun siis kyseessä on fraseologinen yksikkö, sen ensimmäinen osa eli pohjustin (prime) ikään kuin aktivoi toisen osan eli kohdesanan (target) esiintymisen ja vieraskielisessä tekstissä myös sen arvaamisen, mikäli pohjustin on tunnistettavissa äidinkielen perusteella.

Näiden väittämien todistamiseksi laadin testin, johon osallistuneiden vironkielisten informanttien oli käännettävä lyhyt teksti suomeksi ja perusteltava tekemiään valintoja. Yhteensä 47 testatusta suuri osa on yli 20-vuotiaita, osa lukion ensimmäisen luokan oppilaita. Kukaan heistä ei ole opiskellut suomea.

Tulokset osoittavat, että esimerkiksi ala- ja yläkäsitteen välinen tai syy- ja seuraussuhde edistävät merkitysten löytämistä, mutta ulkoiseen samankaltaisuuteen tukeudutaan eniten. Testattavat selittävätkin ratkaisujaan ensisijaisesti sillä, että sanat muistuttavat toisiaan, mutta he nojautuvat myös semanttisten kenttien jäsenyyteen perustuvaan yhteenkuuluvuuteen sekä kontekstiin. 
Tällaiset suhteet edustavat universaalia samankaltaisuutta: ilmiöt luokittuvat lähes samalla tavalla kielistä riippumatta.

Avainsanat: reseptiivinen monikielisyys; konteksti; semanttinen pohjustaminen; fraseologinen yksikkö; kääntäminen; suomi; viro

\section{Johdanto}

Tutkittaessa reseptiivistä monikielisyyttä, kykyä ymmärtää vaikkapa lähisukukieltä äidinkielen pohjalta, keskeisessä asemassa on ollut lähinnä yksittäisten sanojen eriasteisen samankaltaisuuden vaikutuksen arviointi (ks. esim. van Bezooijen \& Gooskens 2007; Kaivapalu \& Muikku-Werner 2010). Viime aikoina on nimenomaan viron ja suomen keskinäistä ymmärrettävyyttä tarkasteltaessa kiinnitetty huomiota toisenkinlaisiin vastaavuuksiin. Kohteena ovat muun muassa fraseologisen yksikön, useamman sanan muodostaman kokonaisuuden, jäsenten väliset linkittymät, joissa semanttisesti vakioinen yhtenkuuluvuus auttaa sanaparin tuntemattoman osan merkityksen löytämistä. (Ks. esim. Muikku-Werner 2015.)

Tällainen lähtökohta nojautuu ajatukseen, jonka mukaan puheyhteisöön kuuluvalla on odotuksia siitä, miten tietyt tarkoitteet ja niitä ilmaisevat sanat kytkeytyvät yhteen. Kognitiiviset kielelliset toiminnot, kuten kyky ymmärtää luettua tai puhuttua tekstiä, vahvistuvat, kun informaatiota ei prosessoida pelkästään yksittäisten sanojen vaan myös käsitekenttien (esim. sukulaiset tai kotieläimet) ohjaamina: täti ja setä, kissa ja koira hahmottuvat helposti odotuksenmukaisiksi ryhmänsä edustajiksi. Lisäksi semanttiseen muistiin perustuva tieto esimerkiksi tekstin aiheeseen liittyvistä seikoista voi myötävaikuttaa ymmärrettävyyteen.

On havaittu, että äidinkielisiä sanapareja vastaavat usein samanmerkityksiset kombinaatiot myös osatuissa vieraissa kielissä. Tästä huomiosta saavat apua sukukieliseenkin tekstiin tutustuvat; enää ei tarvitse keskinäistä ymmärtämistä rakentaa pelkästään ulkoisesti toisiaan muistuttavien kohde- ja äidinkielisten sanojen varassa. Oudolta näyttävän leksikaalisen elementin merkitystä pääteltäessä voidaan hyödyntää 
oletuksia sen ja tunnistetun kera- eli vierussanan kollokatiivisesta, usein tilastollisesti merkitsevästä yhteisesiintymisestä tai muuntyyppisestä linkkiytymisen säännöllisyydestä (kollokoinnista ks. tarkemmin Firth [1968] 1957: 179; Sinclair 1996: 81; Jantunen 2009: 356).

Alun perin sanojen yhdistymistä toisiinsa on testattu erilaisilla reagointikokeilla. Sanaan koira reagoidaan nopeammin silloin, kun sitä edeltävä ärsykesana kuuluu samaan merkityskenttään kuten kissa (reagointitesteistä ks. esim. McNamara 2005 \& Neely 1991). Jokainen sana on ikään kuin virittynyt esiintymään tietyssä merkitysryhmässä: sanalla on semanttisia assosiaatioita (Hoey 2005: 13; ks. myös Pace-Sigge lähteineen 2013: 162). McNamara (2005) käyttää ilmiöstä nimitystä semanttinen pohjustus (engl. semantic priming), jonka aikana käsitteet aktivoituvat semanttisessa muistissa (Collins \& Quillian 1972: 119). Kokemukset sanan aikaisemmasta semanttisesta kontekstista ikään kuin ohjaavat sen uusiokäyttöä (Hoey 2007: 8). Semanttinen pohjustus on läsnä monissa kognitiivisissa tehtävissä, kuten nimeämisessä ja semanttisessa luokittelussa. Se on väline tutkia sanojen tunnistamista, lauseiden ja diskurssin ymmärtämistä ja tiedon representaatiota. Semanttiseen pohjustuksen tuloksena nopeutuvat tai täsmällistyvät niin stimulukseen reagointi kuin muutkin monitasoiset prosessit. Esimerkiksi sanan hakeminen muistista aktivoi myös käsitteeseen kytkeytyvät toiset käsitteet. (McNamara 2005: 3-4, 11.)

Tässä artikkelissa semanttisen pohjustuksen ideaa sovelletaan kuvaamaan nimenomaan fraseologisen yksikön tuntemattoman jäsenen merkityksen päättelyä. Käytän semanttisten assosiaatioiden herättäjänä toimivasta sanasta nimitystä pohjustin (engl. prime) ja sen avulla pääteltävästä ilmauksesta nimitystä kohdesana (engl. target). Kaikki pohjustimeen liittyvä semanttinen informaatio on hyödynnettävissä, kun etsitään sen ja kohdesanan yhteisiä merkityspiirteitä. (McNamara 2005: $11,18,20$.) Siten esimerkiksi pohjustava sukulaissana kallis johtaa kääntämään kohdesanan edullinen sanaksi 'odav' hinta-assosiaation vuoksi.

Oletukseni on, että puuttuvan merkityksen löytämisessä voi käyttää hyväksi kerasanojen välistä semanttista suhdetta, mikäli kohdesanaa 
useimmiten edeltävä, harvoin sen jäljessä tuleva pohjustin on tunnistettavissa äidinkielen perusteella. Pyrin osoittamaan oletukseni todeksi seuraavassa luvussa esittelemäni testin avulla. Tarkoitukseni ei ole väittää, että päättelyprosessia ohjaisivat vain sanojen väliset semanttiset suhteet, vaan kaiken kaikkiaan on tarpeellista selvittää, millaiset erilaiset seikat näyttävät vaikuttavan tehtyihin ratkaisuihin.

Tukeutumalla testituloksiin sekä informanttien kirjaamiin käännösvalintojen perusteluihin pyrin vastaamaan seuraaviin kysymyksiin:

- Miten hyvin virolaiset ymmärtävät suomenkielisiä ilmauksia temaattisesti tutussa joulukontekstissa, jossa etsitty sana kytkeytyy toiseen erilaisten semanttisten suhteiden perusteella?

- Onko löydettävissä joitain tapauksia, joissa oikeaan käännökseen päädytään melko yksimielisesti? Hyödyntävätkö virolaiset ja aiemmin tutkitut suomalaiset tuntemattomien sanojen merkityksiä päätellessään samantapaisia assosiaatioita? Vaikuttaako vastaajien ikä valintoihin?

- Mitkä seikat vaikuttavat vastaajien esittämien perusteiden mukaan käännösvastineen valintaan? Argumentoivatko virolaiset ratkaisujaan samantapaisesti kuin suomalaiset?

Tämä artikkeli on jatkoa LV 25:ssä ilmestyneelle artikkelilleni (MuikkuWerner 2015), jossa käsittelin suomalaisten kykyä ymmärtää vironkielistä tekstiä äidinkielensä pohjalta ja heidän turvautumistaan merkityksen etsinnässä erilaisiin strategioihin, mm. fraseologisten yksiköiden semanttisten sidosten oivaltamiseen.

\section{Testi, testilauseiden valinta ja testatut}

Edellä esittämieni oletusten ja väitteiden todistamiseksi suunnittelin vironpuhujille käännöstehtävän, joka mahdollisimman paljon muistuttaa aiemmin suomalaisille laatimaani testiä (Muikku-Werner 2015: 195-196). Tällöin tuloksia on mahdollisuus edes jossain määrin verrata tosiinsa. Halusin rakentaa fraseologisen yksikön jäsenten välille tiettyjä semanttisia suhteita, joiden uskon osittain helpottavan 
merkityksenpäättelyprosessia. Pelkkään käännökseen tutustuminen antaa kuitenkin vain vihjeitä käytetyistä strategioista, joten testattujen omat näkemykset ratkaisujensa taustoista tuottavat olennaista lisätietoa. Informanttien määrä ei ole kovin suuri, mutta erilaisten käännöstarjokkaiden yhteydessä on siitä huolimatta kerrottu niiden esiintymien määrä. Näin saadaan kuva siitä, millaisia keskittymiä ehdokkaiden valinnoissa on. Siten kvantitatiiviset tulokset havainnollistavat ainakin ratkaisujen välisten erojen suuntia.

Käännettävässä tekstissä pohjustimet on lihavoitu ja kohdesanat kursivoitu.

\section{JOULU ON OVELLA}

Kohta on joulu! Ennen joulua ostamme kinkun. Koristamme kuusen ja leikimme sen ympärillä. Tänä vuonna ostan sukulaisille kirjoja. Toinen kirja voi olla kallis, toinen edullinen.

Katamme pöydän runsaasti: sen päällä on pähkinöitä ja olkisia tähtiä. Maljakossa on yksi hyasintti. Se on kaunis kukka. Paitsi siitä pidän myös ruusuista ja tulppaaneista.

Viime jouluna otimme paljon kuvia. Tässä kuvassa on minun isä ja sisko. Tässä kuvassa puolestaan on minun vaimo. Hän on raskaana. Lapsi syntyi heinäkuussa. Joulupyhinä ihmisillä on aikaa olla perheen kanssa.

Vironkielinen käännös olisi seuraavan kaltainen:

\section{JÕULUD ON UKSE EES}

Kohe on jõulud käes! Jõulu eel ostame singi. Kaunistame kuuse ja mängime selle ümber. Käesoleval aastal ostan sugulastele raamatuid. Üks raamat võib olla kallis, teine odav.

Katame laua rikkalikult. Sellel on pähkleid ning õlgedest tähed. Potis on üks hüatsint. See on ilus lill. Peale selle armastan ka roose ja tulpe.

Möödunud jõulu ajal tegime palju pilte. Sellel pildil on minu isa ja óde. Sellel pildil omakorda on minu naine. Ta on rase. Laps sündis juulis. Jõulupühadel on inimestel aega olla perekonnaga. 
Tekstiä koossa pitävänä teemana on jo otsikossa mainittu joulu siihen liittyvine ilmiöineen. Luottamuksen tekstin yhtenäisyyteen uskotaan helpottavan luetun ymmärtämistä. Lisäksi koherentin kokonaisuuden rakentumista tukevat yksittäisten käsitteiden väliset suhteet. Yleensähän tekstien semanttiset siirtymät perustuvat muun muassa täydelliseen tai osittaiseen toistoon, synonymiaan, antonymiaan, meronymiaan (kokonaisuus-osa-suhteeseen), hyponymiaan (alakäsite-yläkäsitesuhteeseen) ja muihin kytkentöihin (Halliday \& Hasan 1976: 285-292). Käännöstestiä laadittaessa on tietoisesti valittu joitakin edellä mainittuja linkkiytymisen mahdollisuuksia.

Testiin oli käytettävissä noin tunti. Testattavien oli määrä kääntää teksti, mutta kääntäminen ei ollut välttämätöntä. Heitä pyydettiin kiinnittämään huomiota ennen kaikkea tekstin kursivoituihin kohdesanoihin. Ne oli listattu tekstin jälkeen lähinnä käännösratkaisujen selittämistä varten.

Tunnistettavat seitsemän sanaa muistuttavat melko vähän tai tuskin lainkaan vironkielisiä vastineitaan. Ensimmäisen kohdesanan, kinkun, valinnan taustalla on pohjustimen joulu tuottama skemaattinen implikaatio: jouluna ostetaan yleensä muun muassa jouluruokia ja lahjoja (skeemoihin liittyvistä välttämättömistä ja valinnaisista elementeistä ks. Minsky 1975: 212-213; Brown \& Yule 1983: 223-224). Siten kinkun mainitseminen vahvistaa tekstin temaattista koherenssia: Kohta on joulu! Ennen joulua ostamme kinkun (viro: '(jõulu)sink').

Kerasanoja voi yhdistää myös käsitteiden antonyymisyys: Toinen kirja või olla kallis, toinen edullinen (viro: 'soodus', 'odav'). Vierekkäisyyden voi olettaa helpottavan hintavaihtoehtojen hahmottamista. Sen sijaan tekstin ajallista vastakohtaa ilmaisevat sanat sijoittuvat melko kauas toisistaan, joten niiden yhteyden oivaltamista ei voi pitää kovin odotuksenmukaisena: Tänä vuonna ostan sukulaisille kirjoja. --- Viime jouluna otimme paljon kuvia (viro: 'möödunud', 'eelmine').

Semanttiset kentät mahdollistavat myös monenlaista yhteenkuuluvuutta (ks. esim. Larjavaara 2007: 143-152). Tavallisin laji on ala- ja yläkäsitteen välille syntyvä suhde. Valitussa esimerkissä sisältyvyyttä 
rakennetaan mainiten ensin hyponyymi ja vasta sitten hyperonyymi: Maljakossa on yksi hyasintti. Se on kaunis kukka (viro: 'lill'). Jaettu semanttinen kenttä luo edellytykset kohyponyymien eli vieruskäsitteidenkin rinnakkaisuudelle. Testilauseen objekteille on yhteistä se, että ne ovat koriste- tai leikkokasveja: Paitsi siitä [hyasintista] pidän myös ruusuista ja tulppaaneista (viro: 'tulp').

Toisessa esimerkissä kerasanoja sitoo toisiinsa lähisukulaisuus: Tässä kuvassa on minun isä ja sisko (viro: 'õde', 'sõsar'). Nimenomaan siskon valinnan syynä on se, että suomalaisillekin tehdyssä testissä käytettiin sanaa õde. Se seuloutui mukaan siksi, että sinänsä luontevammassa, vanhemmuutta ilmaisevassa parissa isa ja ema sekä pohjustin että kohdesana olisivat olleet tunnistettavissa suomen avulla. Toisaalta haluttiin testata, onko isän ja äidin välinen kytkös niin vahva, että se ohjaisi valitsemaan käännökseksi sanan 'ema' eikä sanaa 'õde’.

Pelkkään semantiikkaan perustuvista sidoksista vapain on tosielämän lainalaisuuksiin perustuva syy- ja seuraussuhde. Tällaista usein juuri maailmantietoon pohjautuvaa suhdetta kutsutaan usein indeksaaliseksi (Enkvist 1975: 42-45). Kun lapsen kerrotaan syntyneen alkukesästä, hänen voidaan päätellä olleen raskaana edeltäneenä jouluna otetussa valokuvassa: Hän [vaimoni] on raskaana (viro: 'rase'). Lapsi syntyi heinäkuussa. Tässä esimerkissä viron pohjalta melko vaikeasti tunnistettavaa kohdesana raskaana edeltää pohjustinta.

Testiin osallistui 47 vironpuhujaa. Vastaajista 36 (ryhmä 1) on lähinnä työikäisiä, valtaosin 20-50-vuotiaita. Vastaajista 11 (ryhmä 2) on lukion 1. luokan oppilaita eli 16-17-vuotiaita. Molemmissa ryhmissä on sekä nais- että miespuolisia vastaajia. Edellisen tutkimukseni (Muikku-Werner 2015) perusteella miesten ja naisten vastauksissa ei ollut merkitseviä eroja, joten en ole tässä artikkelissa kiinnittänyt huomiota vastaajien sukupuoleen. Vastaajien henkilöyttä ei tiedetä, ja heihin viitataan vastauksien yhteydessä esimerkiksi seuraavasti: R1M21. Koodin takana on työikäinen mies, jonka vastauksen järjestysnumero koko ryhmässä on 21. Kukaan testattavista ei ole opiskellut suomea; annettujen vastausten 
perusteella informanteilla on ollut vain joitain satunnaisia kontakteja suomalaisten kanssa. Kaikki ovat opiskelleet jotain vierasta kieltä useimmat englantia.

\section{Suomenkielisten sanojen tunnistaminen}

Käännösvaihtoehtoja kuvatessani olen pitänyt testattavien ryhmät erillään. Ratkaisuun on vaikuttanut se, että vertailukohteena toimivassa suomalaisten testissä ei ollut lukioikäisiä vastaajia. Sitä paitsi on kiinnostavaa katsoa, eroavatko eri-ikäisten tarjoamat vaihtoehdot toisistaan. Erityisesti nuorten vastaajien määrä on niin niukka, ettei tuloksia voi yleistää ja jakaumat voivat olla sattumanvaraisia. Olen kirjannut taulukkoon 1 molempien ryhmien oikeiden käännösten sekä absoluuttiset että suhteelliset osuudet, jotta ryhmienvälinen vertailu onnistuu.

TAulukко 1. Kohdesanojen saamien oikeiden käännösten määrä (vastaajat: $R 1 N=36, R 2 N=11$ )

\begin{tabular}{|c|c|c|c|c|c|c|c|c|}
\hline & 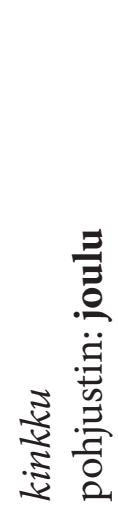 & 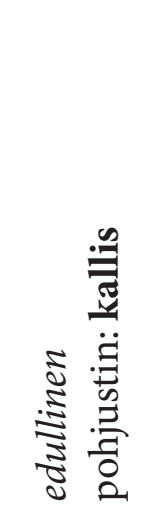 & 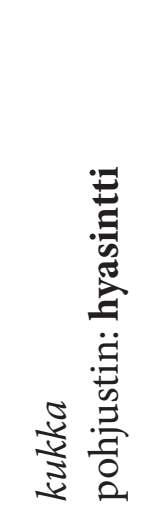 & 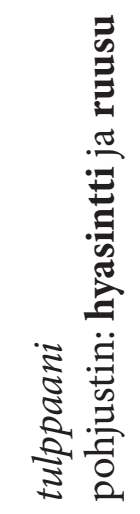 & 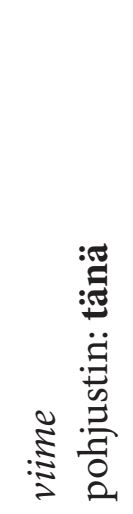 & 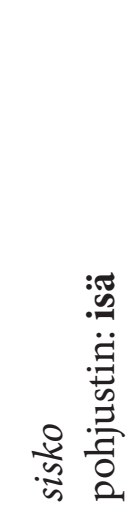 & 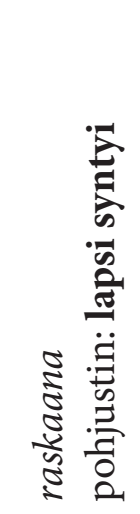 & $\underset{ટ}{\stackrel{્}{二}}$ \\
\hline & $\mathrm{n} / \%$ & $\mathrm{n} / \%$ & $\mathrm{n} / \%$ & $\mathrm{n} / \%$ & $\mathrm{n} / \%$ & $\mathrm{n} / \%$ & $\mathrm{n} / \%$ & $\mathrm{n} / \%$ \\
\hline $\begin{array}{l}\text { Ryhmä } \\
1\end{array}$ & $6 / 16,7$ & $10 / 27,8$ & $19 / 52,8$ & $20 / 55,6$ & $9 / 25,0$ & $33 / 91,7$ & $14 / 38,9$ & $111 / 44,0$ \\
\hline $\begin{array}{l}\text { Ryhmä } \\
2\end{array}$ & $-1-$ & $1 / 9,1$ & $1 / 9,1$ & $3 / 27,3$ & $-1-$ & $10 / 90,9$ & $-1-$ & $15 / 19,5$ \\
\hline
\end{tabular}

Molemmissa ryhmissä on useimmiten käännetty oikein sana sisko. Sinänsä isän ja siskon kytkentä ei ole semanttisesti kaikkein kiintein ydinperheen jäsenyyden kannalta (vrt. isä ja äiti tai veli ja sisko). 
Kiinnostavaa on se, että suomalaisille suunnatussa testissä sanaparista ema ja õde jälkijäsen käännettiin vain kerran 'sisareksi', tavallisimmin 'isäksi' tai jollain muulla sukulaissanalla. Erilainen tulos selittynee sillä, että sisko yhdistetään englannin sister- tai viron sõsar-sanaan, kun taas óde-sanan merkityksen selvittämisessä ei voitu nojautua suomeen eikä tavallisimmin opittuihin vieraisiin kieliin. Siten isän ja äidin linkittäminen toisiinsa vanhemmuuden kautta oli luontevaa suomalaisille suunnatussa testissä. (Muikku-Werner 2015: 199.)

Myös saman semanttisen kentän jäsenyys joko sisältyvyyden tai kohyponyymisyyden perusteella tuottaa lukuisia oikeita käännöksiä. Yli puolet vanhemmista vastaajista kytkee hyasintin yläkäsitteeseen $k u k k a$. Sen sijaan suomalaisista vain n. $40 \%$ päätyi kääntämään lill-sanan 'kukaksi'. Syynä ovat riskisanat, "petolliset ystävät", lilja ja lila. (MuikkuWerner 2015: 198; riskisanoista ks. tarkemmin Laalo 1992; Alvre \& Vodja 1995.) Tulppaanin tunnistamisessa myötävaikuttivat niin muiden kukkien listaaminen kuin viron sanan tulp samankaltaisuus. Sen kaikki suomalaiset omassa testissään käänsivät oikein 'tulppaaniksi' (MuikkuWerner 2015: 198).

Ikäryhmien vastaukset poikkeavat toisistaan selvästi raskaanasanan yhteydessä. Lukiolaisten vastauksista oikea käännös puuttuu. Eroavuuden mahdollisia syitä käsittelen myöhemmin tässä luvussa. Rase suomalaisten testissä oli ainoa sana, jonka merkityksen naiset päättelivät huomattavasti miehiä useammin virheettömästi (Muikku-Werner 2015: 199).

Jouluna ostettavista asioista puhuttaessa kohdesanan 'kinkku' oikea käännös sink ei tule monellekaan työikäiselle mieleen (n. 16 \%:lle vastaajista), kouluikäisille ei kenellekään. Tässä tapauksessa ratkaisuun on voinut vaikuttaa joko suomen ja viron sanojen alkukirjaimen erilaisuus tai ennen kaikkea riskisana kink, kingitus 'lahja'. Kun jatkossa vielä puhutaan lahja-käsitteen alakäsitteestä kirja, kinkku ei ehkä hahmotu yhtä luontevasti tekstikokonaisuuden osaksi. Suomalaisille tehdyssä testissä asetelma on päinvastainen: käännettävänä on kingitus 'lahja', ja oikeaan vaihtoehtoon päätyi yli 60 \% vastaajista. Väärien käännösten määrälliset 
erot virolaisten ja suomalaisten vastauksissa johtunevat siitä, että toisin kuin suomen kinkku helposti tuo mieleen viron sanan kink 'lahja', kingitus ei yhtä paljon muistuta suomen kinkku-sanaa. Silti 'kinkkua' tarjosi käännökseksi yli 30 \% vastaajista (Muikku-Werner 2015: 200).

Kallis-pohjustimen pariksi on valittu antonyymi edullinen. Sen asemesta ei voinut käyttää halpa-sanaa, koska se olisi sotkeutunut viron sanaan halb 'huono'. Vaikka fraseologisen yksikön ensijäsenen kallis luulisi helposti yhdistyvän vastakohtaansa, näin ei käy: työikäisistä vain alle $30 \%$ ja lukiolaisista $10 \%$ valitsee hinnan huokeuden toteavan ilmauksen. Suomalaisista yli $80 \%$ päätyi vastaavassa tapauksessa kääntämään sanan odav 'halvaksi' (Muikku-Werner 2015: 198). Osittain tilanne selittyy sillä, että jotkut virolaiset testattavat ovat ymmärtäneet suomen kirjan 'kirjeeksi' (vir. kiri vrt. raamat 'kirja'), mikä on vienyt pohjan hintateeman käsittelyltä.

Ajallinen vertailu nykyisen ja edellisen joulun välillä onnistuu noin neljännekseltä vastaajia. Tulos on samansuuntainen työikäisillä virolaisilla ja suomalaisilla testattavilla. Vaikka tänä tai käesolev sijoittuu tekstissä etäälle vastaparistaan viime tai möödunud, joissain vastauksissa tapahtumat sijoittuvat korrektisti aikajatkumolle.

Taulukoissa 2 ja 3 esittelen oikeiden käännösten ohella myös muut ehdotukset. Annan esimerkkejä erilaisista tekstikokonaisuuksista, joihin kohdesanatarjokas saadaan melko loogisesti sijoitettua. Puuttuvat vastaukset, kysymysmerkit ja ymmärtämättömyyden toteaminen on kaikki sijoitettu ei vastattu -kategoriaan. ${ }^{*}$-merkillä varustetut vaihtoehdot eivät ehkä ole käännöksiä vaan mahdollisesti toistavat suomenkielisen kohdesanan sellaisenaan; tosin kääntäminen on toinen selitysvaihtoehto.

Kuten edellä on mainittu, 'lahja'-käännöksen valinta 'kinkun' asemesta selittyy riskisanan (kink, kingitus) samankaltaisuudella. Vastaajat ovat varsin yksimielisiä: sink-vaihtoehtoja on vähän. Kiinnostavasti poimitaan jouluaterioihin soveltuvien ruokalajien semanttisesta kentästä myös 'kana' ja 'kalkun' Vastausten perusteella ei sinänsä voi varmasti sanoa, onko yhteinen alkukirjain $k$ jollain tavoin ohjannut tätä valintaa. Toisaalta viron kints : kintsu 'reisi, koipi' voi tarkoittaa esimerkiksi 


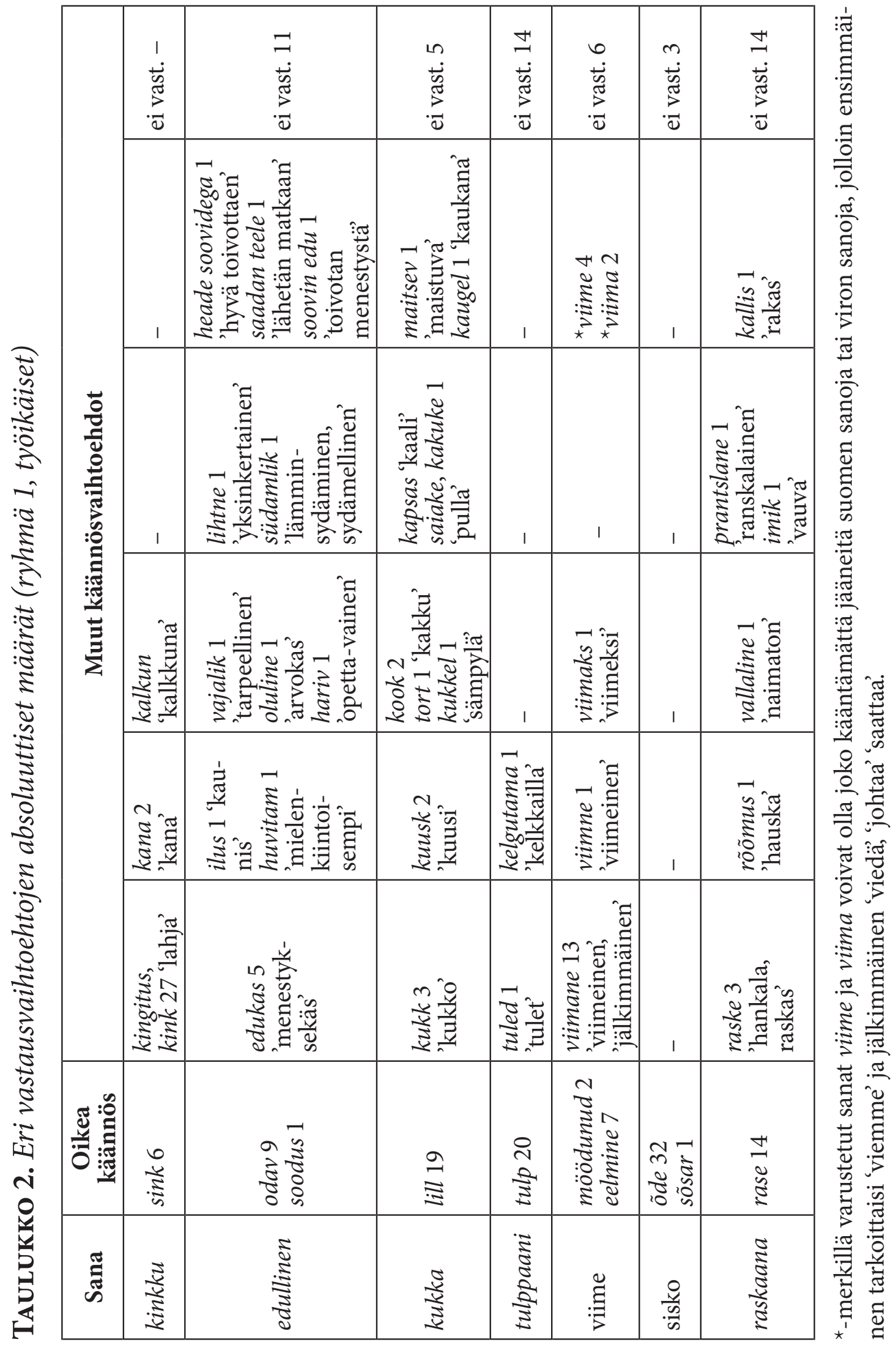


'kanankoipea', sillä kaupoissa myydään kanan tai kalkkunan "kintsulihaa”. Myös tämä assosiaatio voisi johtaa ratkaisuun.

Eniten vaihtoehtoisia käännöksiä liittyy kohdesanaan edullinen. Oikeita vastauksia (odav, soodus) on melko paljon, mutta myös petollinen ystävä edukas saa kannatusta. Kun suomen sanan alusta on samankaltaisuuden perusteella poimittu aines $e d u$, viron 'menestys', päästään myös sanaan edukas 'menestyksekäs'. Muiden ehdotusten takana on lähes aina vain yksi henkilö, ja ne kertovat useimmiten toisen kirjan hyvistä ominaisuuksista, kuten kiinnostavuudesta tai opettavaisuudesta. Jos tekstin toinen ja toinen -asetelma muuntuu jokin ja jokin -pariksi, vastakohtaisuuden ilmaisemisen tarve hieman vähenee, mikä näkyy seuraavasta käännöksestä: Mõni raamat võib olla kallis, mõni vajalik R1N9 'Jokin kirja voi olla kallis, jokin tarpeellinen'. Kun kirja on yhdistetty viron sanaan kaart 'kortti', menestyksen toivottaminen sopii kontekstiin hyvin: Täna ostan sugulastele postkaarte. Soovin edu R1M22 'Tänään ostan sukulaisille postikortteja. Toivotan menestystä. Korttiin voi sisällyttää myös kaiken hyvän toivotuksia (heade soovidega R1N5). Jotkin valituista adjektiiveista sopivat puolestaan 'kirje'-merkityksen pohjalta rakennettuun kontekstiin: Sel aastal saadan sugulastele kirjad. Kiri voib olla väike, aga südamlik R1N15 'Tänä vuonna lähetän sukulaisille kirjeitä. Kirje voi olla lyhyt mutta lämminsydäminen'.

Tekstissä mainittujen, melkoisesti viron sanoja muistuttavien koristekasvien hyasintti, ruusu ja tulppaani yläkäsite lill 'kukka' on suosituin käännöstarjokas. Muista ehdokkaista 'kukko' on valittu muutaman kerran. Kaikki sitä tarjoavat eivät kuitenkaan ole sitoneet ehdotustaan kontekstiin, osaksi koko tekstin käännöstä, vaan kukko on mainittu erillisessä kohdesanalistassa. Mikäli tekstissä edellä mainittu maljakossa oleva hyasintti sivuutetaan, kukon laatu todetaan lyhyesti: See on kaunis kukk R1M22 'Se on kaunis kukko.'

Jos testattava jättää hyasintin huomiotta, mahdollistuu se, että kappaleen alussa kuvatulle katetulle pöydälle sijoittuu pähkinöiden seuraksi erilaisia leivonnaisia tai muuta syötävää: Se on ilus tort R1M24 'Se on kaunis kakku'. 'Kuusi'-käännös mahdollistuu, kun pöydän rajaama 
lokaalinen ulottuvuus laajenee käsittämään koko huoneen: Seal on kaunis kuusk R1N34 'Siellä on kaunis kuusi'. Tilaan liittyy myös 'kaukana'vastine: See on päris kaugel R1M1 'Se [hyasintti] on melko kaukana'. Aiempien tutkimusten perusteella on tuttua, että irrallisia, ilman tekstiyhteyttä olevia lauseita kääntävä saattaa tuottaa järjellisiä kokonaisuuksia nojautuen väärin ymmärtämäänsä sanaan (Paajanen 2012: 25-28), mutta tekstikokonaisuuteen kuuluvatkin virkkeet voivat johtaa uusien teemojen kehittelyyn yksittäisten sanojen virhetulkintojen pohjalta (Muikku-Werner 2013: 226-227).

Tulppaani ei tuota kääntäjille ongelmia, mikä viron sanan tulp ja englanninkielisen sanan tulip (vrt. myös saksa die Tulpe) samankaltaisuuden pohjalta onkin odotuksenmukaista. Tarjokas 'kelgutama' saa ympärilleen sopivan kokonaisuuden: [Maja on üksi keset metsa. See on kaunis kuusk.] Siit pidin ma uisutama ja kelgutama R1N33 '[Talo on yksin keskellä metsää. Se on kaunis kuusi.] Täältä minun piti luistella ja kelkkailla'. Mahdollisesti sana maljakko johtaa käännökseen 'maja', vaikka virossa on sana malja 'kulho', jonka voisi olettaa assosioituvan toisenlaiseenkin astiaan. 'Kuusk' puolestaan alkaa samoilla kirjaimilla kuin kukka. Vastaaja ei kommentoi valintojaan, joten prosessista ei voi sanoa mitään varmaa.

Viime-sana tunnistetaan hyvin. Muutkin kuin oikeat käännökset sidostuvat jollain tapaa aikaan: Viimastel jõuludel tegime palju pilte R1N26 'Jälkimmäisenä jouluna otimme paljon kuvia’. Erilaisia valintoja ohjannee usein sukukielisten sanojen samankaltaisuus. Myös siskosanan yhteydessä samankaltaisuus (taustalla engl. sister, jossain määrin myös vir. sõsar) auttaa virolaisen vastineen löytämistä. Muita vaihtoehtoja ei edes tarjota.

Rase-sanan sidostuminen seuraavassa lauseessa kerrottuun lapsen syntymiseen ei ole kovin tavallista. Niinpä vaimo voi kääntäjien mielestä olla paitsi 'raskaana' myös 'rakas', 'hauska' tai 'ranskalainen'. Valintaan Ta on imik R1N14 'Hän on vauva' päätyminen nojautuu siihen, että edellisen lauseen sana vaimo on käännetty lapseksi, jonka ikä nyt täsmennetään. 'Raskas'-merkitys liittyy luotuun kontekstiiin, jossa puheena 
olevan henkilön on huolehdittava valokuvauksesta, mikä on raskasta. 'Naimaton'-sanan ehdottaja ei ole kääntänyt tekstiä, mutta perustelee ehdotustaan nimenomaan tekstilähtöisyydellä: järgmine lause tundus nagu lapsi ei oleks R1N23 'jälkimmäinen lause kuulostaa siltä kuin lapsia ei olisi.

Lukiolaiset (ks. taulukko 3) kääntävät kinkku-sanan lähes yksimielisesti 'lahjaksi'. Vain yksi testattava jättää vastaamatta. Riskisanan kink (tai kingitus) samankaltaisuuden ja jouluskeeman antaman tuen yhteisvaikutus tekee ratkaisusta perustellun.

Kallis-sanaan kytketään vaihtoehdoksi jokin myönteinen ominaisuus, kuten merkittävyys tai arvokkuus. Joskus 'kirja'-sanan asemesta käännösvastineeksi valikoituu 'kirje' (kiri). Kirjeessä voidaan kirjoittaa toisen olevan rakas (viron kallis-sanan toinen merkitys) ja antelias, tai siinä toivotetaan vastaanottajalle menestystä: Kirjutan kirjas, et ta on väga kallis, soovin edu R2N5' 'Kirjoitan kirjeessä, että hän [sukulainen] on rakas, toivotan menestystä.

Pöydällä olevan hyasintin yhteydessä mainittu maljakko-sana osoittautuu hankalaksi. Jos sen merkitystä ei tiedetä, etu hyasintin ja hüatsintin melko identtisestä ulkoasusta menetetään, ja vaasissa viihtyvien koristekasvien yläkäsite $k u k k a$ kääntyy seuraavassa virkkeessä esimerkiksi sitä muistuttavaksi sanaksi kukk 'kukko'. Kukon - tai sen innoittamana mieleen tulleen kanan - sijoittaminen loogiseen ympäristöön tuottaa erilaisia vaihtoehtoja, joiden valintaa pohjustanee ehdokkaiden ja suomenkielisen sanan samankaltaisuus: Majupalaks on üks lind. Se on kaunis kukk R2N8 'Makupalaksi on lintu. Se on kaunis kukko' tai Majas on üks lind. Se on kaunis kana R2M1 'Huoneessa on lintu. Se on kaunis kana'. Kiinnostavasti lukiolaiset, toisin kuin työikäiset, konstruoivat tekstin, johon kukko ja kana luontevasti sijoittuvat. Huoneessa voi olla myös kuusi (vir. 'kuusk'). Rakennukseen liittyy myös seuraava vaihtoehto: Majake on üksildane ja mahajäetud. See on kaunis vaatepilt R2N10 'Mökki on syrjäinen ja hylätty. Se on kaunis näkymä. Kukkateeman puute johtaa aivan toisentyyppiseenkin aiheeseen siirtymiseen: See on kaunis aeg R2N5 'On kaunista'. 


\begin{tabular}{|c|c|c|c|c|c|c|c|}
\hline \multirow{7}{*}{ 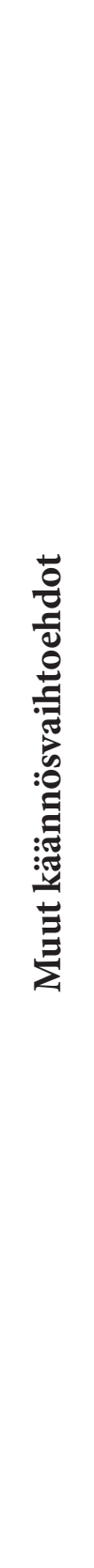 } & $\begin{array}{l}\overrightarrow{+} \\
\dot{\vec{s}} \\
\stackrel{\Xi}{0} \\
\overrightarrow{0}\end{array}$ & $\begin{array}{l}m \\
\dot{0} \\
\tilde{D} \\
\dot{0} \\
\dot{0}\end{array}$ & 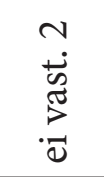 & 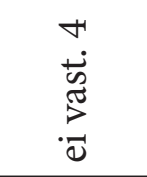 & 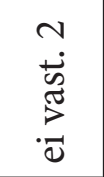 & $\begin{array}{l}1 \\
\dot{0} \\
\stackrel{0}{0} \\
\dot{0}\end{array}$ & 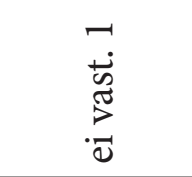 \\
\hline & I & 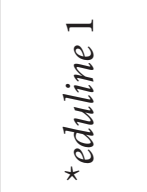 & 1 & 1 & 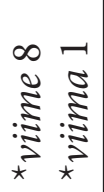 & & 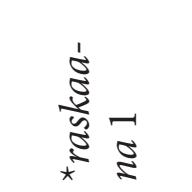 \\
\hline & 1 & 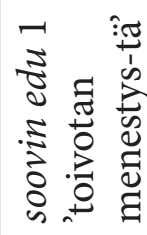 & 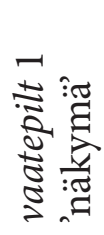 & 1 & 1 & 1 & 1 \\
\hline & I & 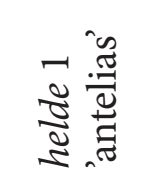 & 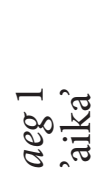 & 1 & 1 & I & 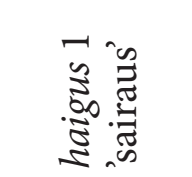 \\
\hline & I & 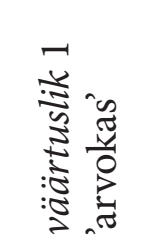 & 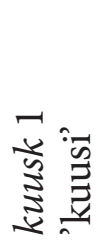 & 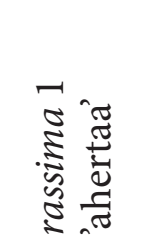 & I & I & 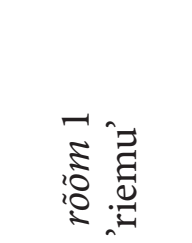 \\
\hline & 1 & 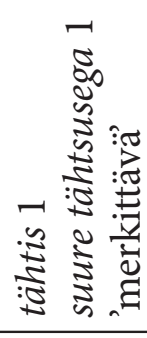 & $\vec{z}$ & 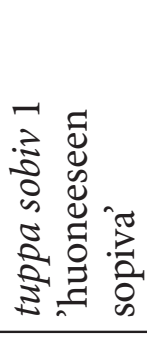 & I & 1 & 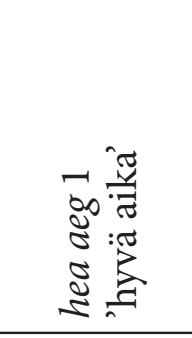 \\
\hline & 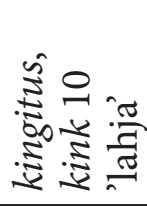 & 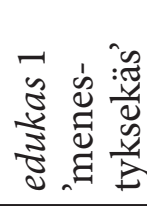 & 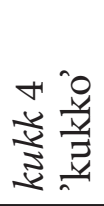 & 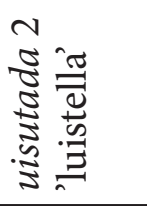 & I & 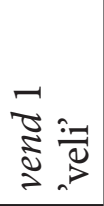 & 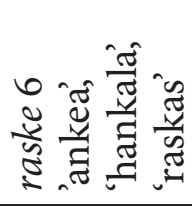 \\
\hline 营: 䒿 & $\frac{1}{\frac{z}{5}}$ & 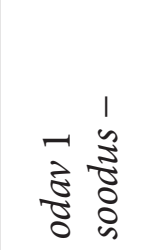 & 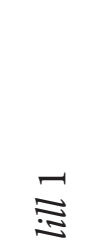 & $\stackrel{n}{3}$ & 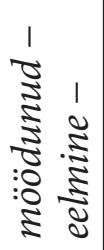 & $\begin{array}{l}0 \\
\frac{1}{10} \\
10\end{array}$ & 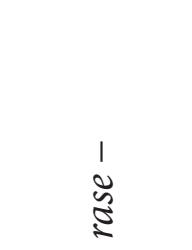 \\
\hline ڤ్చే & $\frac{\frac{\sqrt{2}}{3}}{\frac{\pi}{3}}$ & 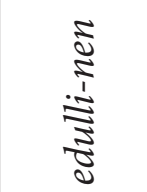 & $\frac{\widetilde{\pi}}{\underline{\underline{Z}}}$ & $\begin{array}{l}\frac{\pi}{3} \\
\frac{3}{1} \\
0 \\
0 \\
0 \\
0\end{array}$ & $\underset{\Xi}{:}$ & $\frac{8}{\frac{8}{6}}$ & 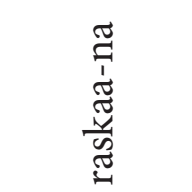 \\
\hline
\end{tabular}


Tulppaania ei tunnista kuin muutama vastaaja, mikä selittyy edellä mainitusta teeman ohjautumisesta uusille alueille. Tällöin käsiteltäviksi sopivat vaikkapa talviset liikuntalajit tai muut arjen askaret: [See on kaunis aeg.] Mulde meeldib suusatada ja uisutada R2N5 'Minua miellyttävät hiihtäminen ja luisteleminen' tai [Majake on üksildane ja mahajäetud. ---.] Siin ma pidin tassima ja rassima R2N10 'Täällä minun piti raahata ja ahertaa. Tulppaani voi korvautua myös samantapaisella sanalla tupa 'huone': Peagi pean mina seda [hyasinttia] ilusaks ja tuppa sobivaks R2N6 'Kohta pidän sitä kauniina ja huoneeseen sopivana'.

Viime-sanaa ei välttämättä käännetä, vaan tarjotaan suomen sanaa sellaisenaan: 'viime jõuludel'. Tosin 'viime' voisi olla tässä esimerkissä viron verbi: 'viemme jouluna'. Tällöin virkkeen loppu otimme paljon kuvia ei taivutettuine verbeineen enää sovi tekstiyhteyteen.

Sisko-sanan käännöksestä lukiolaiset ovat lähes yksimielisiä. Kun samankaltaisuus ohjaa useimpia ratkaisuja, onkin erikoista, että yksi vastaajista päätyy sanaan vend 'veli' R2N10. Sen sijaan että tukeutuisi isän ainakin potentiaalisesti pohjustamaan vanhemmuuden kategoriaan ja esittäisi sanaa äiti, hän valitsee saman ydinperheen tason, johon siskokin kuuluu. Kun suomalaiset testattavat eivät tunnista pohjustimeen ema liittyvää kohdesanaa õde, toisen vanhemman pariksi ehdotetaan hyvin usein sanaa 'isä' (Muikku-Werner 2015: 199).

Raskaana-sanaa ei tunnista yksikään lukiolainen. Edeltävän lauseen vaimo yhdistetään ilmeisesti viron sanaan vaim 'tunnelma', 'henki', 'sielu'. Siten jatkotekstin käännöstä ohjaavat yleiset arviot jouluajan laadusta, sen tuottamasta hengestä tai mielialasta: On rasked ajad R2M1 'On hankalat [tai raskaat] ajat' tai Küll on hea aeg R2N5 'Kyllä on hyvä aika'. Joskus vaim ymmärretään 'mieleksi', jonka on todettu olevan täynnä onnea. Tällöin on luontevaa jatkaa seuraavasti: See on täis rõõmu R2N8 'Se on täynnä iloa'. Henkilön kuvaamiseen tarjoutuu tietysti lukemattomia mahdollisuuksia, jos häneen ei kytketä lapsen syntymistä: Tal [tädillä] on haigus R2N10 'Hänellä on sairaus'. Ulkoinen samanlaisuus selittänee rõóm-sanan valinnan, mutta muut vaihtoehdot rakentunevat testattavien vapaiden assosiaatioiden varaan. 
Edellä esitetyt havainnot osoittavat, että osa käännösehdotuksista tukeutuu sanojen ulkoiseen samankaltaisuuteen, osa niiden tuottamiin semanttisiin assosiaatioihin. Monet tarjokkaat sopivat loogisesti uuteen kontekstiin, joka perustuu virheelliseen käännökseen. Joskus valinnat pohjautuvat useaan rinnakkaiseen syyhyn. Lukiolaisten ja työikäisten väliset erot voivat syntyä monen muuttujan yhteisvaikutuksesta. Vanhemmille vastaajille on ehkä kertynyt sekä enemmän kokemusta petollisista ystävistä, joita osataan varoa, että runsaammin kontakteja suomen kieleen. Testattavien ilmaisemiin perusteluihin syvennytään seuraavassa luvussa.

\section{Käännösvalintojen perusteluja}

Edellisessä luvussa on esitelty annettuja käännösvaihtoehtoja. Paitsi niihin on kiinnostavaa tutustua myös siihen, miten testatut selittävät tekemiään ratkaisuja. Seuraavaksi kuvailen joitain tyypillisimpiä tapoja hahmottaa ilmausten ja ilmiöiden välisiä suhteita. Valitettavasti lukiolaiset ovat tyytyneet yleensä vain käännökseen, minkä vuoksi vastauksissa painottuvat iäkkäämpien näkemykset.

Tavallisimmin valintoja tehtäessä näkyy tukeudutun ulkoiseen samankaltaisuuteen. Tämä tulos on odotuksenmukainen ja jo useissa eri tutkimuksissa todennettu (Kaivapalu 2005: 271; Kaivapalu \& MuikkuWerner 2010: 83). Valitettavasti liiallinen luottamus yksi yhteen -suhteeseen johtaa monesti väärään tulokseen. Joulun teema luo hyvät edellytykset riskisanan kinkku (vir. sink) kääntämiseen sanalla kink 'lahja' (1). Eräs niistä, jotka kuitenkin päätyvät ruokien viitekehykseen, valitsee - ehkä omien suosikkiensa perusteella - 'kalkkunan' (ks. selitys s. 320) (2). Toki alkukirjain $k$ voi osaltaan tukea ainakin Suomessa harvinaisemman ateriatarjokkaan esittämistä.

(1) kinkku $\rightarrow$ kalkun 'kalkkuna': Söövad kalkunit jöuludel. (R1N19) 'Syövät jouluna kalkkunaa.' 
(2) kinkku $\rightarrow$ kingid 'lahjat': Eelnev lauseosa oli: "Ennen joulua ostamme..." See meenutab väga eesti keelt: Enne jõule ostame... Ja tavaliselt ostetakse enne jõule kinke. (R2M1)

'Osa edeltävästä lauseesta oli: Ennen joulua ostamme... Se muistuttaa vironkielistä: Enne jõule ostame... Ja tavallisesti ennen joulua ostetaan lahjoja.'

Kukka puolestaan yhdistetään - kasviteeman vaihduttua toiseksi - viron sanoihin kook, kakuke tai kukk (ks. esimerkit 3-5). Kuulostaa-verbin käyttö voi viitata siihen, että asianomainen on hyödyntänyt "hiljaista" ääneen lukemista päätöksiä tehdessään (4). Tähän strategiaan turvautuminen on tuttua aiemmistakin tutkimuksista (Kaivapalu \& MuikkuWerner 2010: 83; Paajanen \& Muikku-Werner 2012: 241).

(3) kukka $\rightarrow$ kook 'kakku': Pakun et kook. (R1M21) 'Tarjoan kakkua.'

(4) kukka $\rightarrow$ kapsas, saiake, kakuke: kõlab nii. (R1N19) 'kaali, pikkupulla, pullasämpylä: kuulostaa siltä.'

(5) kukka $\rightarrow$ kukk 'kukko': Se on väga sarnane eeti keele sõnaga 'kukk'. (R2N8)

'Se on hyvin samanlainen kuin eestin kielen sana 'kukk".

Toki samankaltaisuudesta on hyötyäkin. Se hahmotetaan usein perusmuodosta käsin. Tällöin saatetaan jopa kiinnittää huomiota taivutukselliseen seikkaan, tekstissä olevan kohdesanan monikollisuuteen (6). Metalingvististä tietoisuutta edustaa myös muun kuin sukukielen käyttäminen merkityspäättelyn alkupisteenä (7). Englannin on aikaisemminkin huomattu olevan tärkeä lähtökohta (Muikku-Werner \& Heinonen 2012: 179; Paajanen \& Muikku-Werner 2012: 238).

(6) tulppaani 'tulp': sarnaneb eesti keele sõnaga, on ainult mitmuses (R1N26) 'muistuttaa viron sanaa, on vain monikossa [testissä tulppaaneista]'

(7) sisko 'õde': ingliskeelsest sõnast sister, ilmselt tähendab õde. (R1M4) 'englanninkielisestä sanasta sister, ilmeisesti tarkoittaa siskoa'

Maailman polarisointi ja ilmiöiden vastakkainasettelu ovat luonteenomaista ihmisille (Larjavaara 2007: 146). Mikäli tekstin alkuperäinen 
konteksti (lahjakirjojen hintavertailu) säilyy käännöksessä, antonyymisen suhteen hahmottaminen kalliin ja halvan välillä onkin helppoa (8 ja 9). Samoin tänä ja viime jouluna hahmottuvat oikeiden ratkaisujen perusteella kahdeksi vastakkaiseksi aikaulottuvuudeksi, mutta perusteluissa asiaan ei juuri viitata (10). Toisiinsa kytkeytyvien sanojen etäisyys on pitkä, joten yhteys niiden välillä ehkä havaitaan vähemmän tietoisesti ja sen kommentointi jää puuttumaan.

(8) edullinen 'odav': Kui üks on kallis, siis äkki teine on odav. (R1N2) 'Kun yksi on kallis, niin varmaankin toinen on halpa.'

(9) edullinen 'odav': Lihtsalt sõna kallis vastand. (R1M12) 'Yksinkertaisesti sanan kallis vastakohta.'

(10) viime 'eelmine': Väljend 'viime vuonna' meenus, mis on 'eelmisel aastal'. (R1N6)

'Ilmaus 'viime vuonna' muistuttaa, mikä on 'edellisenä vuonna.'

Myös ala- ja yläkäsitteiden välinen suhde auttaa hahmottamaan asioiden yhteenkuuluvuutta. Se puolestaan edistää tekstin ymmärtämistä. Sekä hyasintit että tulppaanit sidostuvat kukka-käsitteeseen (11-13). Perhe puolestaan tarjoaa siskolle semanttisen viitekehyksen (14).

(11) kukka 'lill': Arvan, et se on lill kuna eelnevas lauses on hüatsinti mainitud, mis on lill (R2N6)

'Arvaan, että se on kukka sillä edellisessä lauseessa on mainittu hyasintti, joka on kukka.'

(12) kukka 'lill': Arvasin, et "hyasintti" on hüatsint. Ehk siis järgmine lause kirjeldab hüatsinti, öeldes, et see on ilus lill. (R1N10)

'Arvasin, että "hyasintti" on hüatsint. Eli siis seuraava lause kuvailee hyasinttia kertoen, että se on kaunis kukka.'

(13) tulppaani 'tulp': Meenutab sõna tulp, kuna jutt käis lilledest. (R1M12)

'Muistuttaa sanaa tulppaani sillä puhe oli kukista.'

(14) sisko 'õde': On aru saada, et lause käib pere kohta. (R1M1)

'Voi ymmärtää, että lauseessa puhutaan perheestä.'

Samaan semanttiseen kenttään kuuluminen helpottaa vieruskäsitteiden löytämistä varsinkin, jos aihepiiri kaiken kaikkiaan tukee kytköksen havaitsemista. Mikäli toinen kohyponyymi on esimerkiksi 
samankaltaisuuden perusteella käännetty väärin, toinen käsite sopeutetaan siihen: kukko saa seurakseen kanan (15). Vastaavasti isä pohjustaa kyllä ydinperheen jäsenyyttä, mutta valinta osuu virheellisesti veljeen siskon asemesta (16).

(15) kukka $\rightarrow$ kana: Kukk ja kana. (R2M1) 'Kukko ja kana.'

(16) sisko $\rightarrow$ vend 'veli': mingi pereliig (vend?) sest on isa ja keegi veel (R2N10) 'joku perheenjäsen (veli?) koska on isa ja vielä joku'

Tosielämän syy- ja seuraussuhteet eivät ole kielikohtaisia. Siten jos testattava ymmärtää, että tekstissä puhutaan ensin valokuvassa olevasta kertojan vaimosta ja pari lausetta myöhemmin lapsen syntymisestä, raskaana olemisen päättely onnistuu, vaikka välilauseeseen sijoittuva raskaana-sana olisikin vieras. Sitä paitsi se muistuttaa ulkoisestikin rasesanaa. Esimerkissä (18) raskaana on kuitenkin sisko, joka tosin on tekstissä mainittu aikaisemmin.

(17) raskaana 'rase': järel lause, justkui laps sünnib heinäkuul. (R1N36) 'perässä lause, ikään kuin lapsi syntyy heinäkuussa.'

(18) raskaana 'rase': Jutt käis õest ja nü̈̈d tuli sõna, mis meenutab eesti keeles sõna "rase", seega võib eeldada, et õde on rase. Ka järgmine lause viitab sellele, öeldes, millal laps sündima peaks. (R1N10)

'Puheena on sisko ja nyt tuli sana, joka muistuttaa viron kielen sanaa "rase", minkä perusteella oletan, että sisar on raskaana. Ja seuraava lause viittaa siihen kertoen, milloin lapsen pitäisi syntyä.'

Esimerkistä (19) näkyy, miten tulkinnoissa käytetään apuna erilaista tietoa kielestä ja käsitteiden välisistä suhteista. Asianomainen hyödyntää yhtäältä kukka-hyperonyymiä ja toisaalta viron tulp- ja suomen tulppaani-sanan samanlaisuutta. Se että tulppaanien kuuluminen jouluiseen kotiin on kyseenlaistettavissa, paljastaa jouluskeeman erilaiset täytöt: kaikki leikkokukat eivät ole yhtä odotuksenmukaisia kaikissa kulttuureissa. Myös esimerkistä (20) ilmenee hyvin, miten prosessi etenee. Edullinen-sana johtaa samankaltaisuuden kautta sanaan edukas, joka puolestaan synnyttää myönteisiä mielteitä. Kirjoittaja päätyykin 
käännökseen ilus 'kaunis' kuvatessaan huonetta: Maja on nüüd hästi ilus R1M4 'Huone on nyt hyvin kaunis'.

(19) tulppaani 'tulp': Jutt käis lilledest ja sõna on väga sarnane eesti keele "tulpidele", seega arvasin, et ehk võib juttu tõesti tulpidest olla. Samas tundub kahtlane, miks peaks jõulude ajal tulbid kodus olema. (R1N10) "Puhe oli kukista ja sana on hyvin samanlainen kuin viron "tulpidele", siten arvelin, että ehkä tosiaan puhutaan tulppaaneista. Samalla tuntuu epäilyttävältä, miksi jouluaikaan pitäisi kotona olla tulppaaneja.'

(20) pole õrna aimugi aga eestikeelsest sõnast edukas pakkusin, et on midagi positiivset (R1M4)

'ei ole aavistustakaan mutta viron sanasta edukas arvelin että jotain positiivista'

Esimerkissä (21) olevan tekstin tuottanut vastaaja on kääntänyt tekstin seuraavasti: Sellel pildil on minu laps. Ta on raske (R1M4) 'Tässä kuvassa on lapseni. Hän on hankala'. Perusteluissaan testattava kuvaa, miten toisiinsa liittymättömät asiat muuttavat päättelyprosessin suuntaa ja raskaana-sanalle löydetään merkitys samankaltaisuuteen tukeutuen.

(21) esialgu arvasin et rase, aga tekstis oleks siis et laps on rase. Äkki on raske tulenedes eestikeelest. (R1M4)

'ensin arvasin että raskaana, mutta tekstissä olisi silloin että lapsi on raskaana. Varmaan raske tulee viron kielestä.'

Vastaajat eivät aina ole täysin varmoja ratkaisuistaan, minkä he mielellään myös tuovat esille (22). Usein epäröinti aiheutuu juuri siitä, ettei ehdotettu käännös tunnu sopivan kontekstiin. Merkityksen päättelijä hämmentyy sanojen ulkoisesta samankaltaisuudesta, joka kuitenkin johtaa lopulliseen valintaan (23).

(22) "Kaugel" ma arvan. (R1M1)

'"Kaukana", arvaan.'

(23) Ei tea, ütleks kukk. aga ei lähe kuidagi teksti kontekstiga kokku. (R1M4) 'En tiedä, sanoisin kukko. mutta jotenkin ei käy yhteen kontekstin kanssa' 
Edelliset näytteet kannanotoista osoittavat, että sukukielen ymmärtämisprosessi nojautuu hyvin monenlaiseen lingvistiseen tietoon, vaikka vastaajat eivät ole kielentutkimuksen asiantuntijoita (ks. vastaavista tuloksista Hufeisen \& Marx 2007: 308; Singer 2007: 343). Esitetyissä perusteluissa vedotaan samankaltaisuuteen, tekstin loogisuuteen ja fraseologisen yksikön jäsenten väliseen merkityssuhteeseen. Siten toteutuu oletus, jonka mukaan sukukielisestä tekstistä on mahdollista hahmottaa ymmärrettävä kokonaisuus tukeutuen paitsi yksittäisiin sanoihin myös käsitteiden semanttisiin kytköksiin. Virolaiset ja suomalaiset testattavat kuvaavat käännösehdotustensa valintaa hyvin samantapaisesti (MuikkuWerner 2015: 204-209).

\section{Pohdintaa}

Virolaisten käännösratkaisuja ohjaa hyvin usein sukukielten sanojen ulkoinen samankaltaisuus. Se on vaikuttajista vahvimpia, mikä näkyy verrattaessa virolaisten sisar- ja suomalaisten óde-sanan käännöksiä. Edellinen tunnistetaan ja päädytään oikeaan ratkaisuun. Suomalaiset hyödyntävät edeltävää ema-sanaa ja poimivat sen semanttisesti luontevaksi pariksi isän, koska õde-on tuntematon.

Liika luottamus samankaltaisuuteen johtaa myös harhaan, kuten jo monissa tutkimuksissa aiemminkin on todettu. Kun yksi sana käännetään väärin, koko teksti etsii uusia merkitysulottuvuuksia, kuten on nähtävissä esimerkiksi kirjan ja kirjeen sekä kukan ja kukon sekoittamisen yhteydessä.

Fraseologisen yksikön kohdesanan merkityksen löytäminen edellyttää ennen kaikkea sitä, että pohjustin kyetään tunnistamaan kielisukulaisuuden perusteella. Täyttä varmuutta siitä, ohjaako nimenomaan testin laatijan pohjustimeksi ajattelema sana käännösprosessia, ei ole saatavilla, vaikka joidenkin osallistujien kuvaukset valintojensa perusteista viittaavat tähän syy- ja seuraussuhteeseen. Luonnollisesti myös tekstin teemalla ja lähikontekstilla on merkitystä ratkaisujen tekemisessä. 
Tietyt semanttiset kytkökset, kuten sisältyvyys sekä syy- ja seuraussuhde, jotka liittyvät ehkä ilmeisimmin äidinkielen käsitejärjestelmän hallintaan, tuntuvat eniten helpottavan outojen suomenkin sanojen ymmärtämistä. Merkityssuhteisiin perustuva päättely ei ole sidoksissa pelkästään kielisukulaisuuteen, sillä semanttiset kentät rakentuvat universaalisti varsin samoin tavoin. Myös käsitykset koherentin ja loogisen tekstin ominaisuuksista jaetaan monissa kulttuureissa. Siten samankaltaisuus saa entistä laajempia ulottuvuuksia.

Virolaiset ja suomalaiset argumentoivat käännösratkaisujaan hyvin samantapaisesti, mikä viittaa siihen, että niin leksikaalisten yksiköiden linkkiytyminen toisiinsa kuin kontekstin ja yhtenäisen koherentin tekstin vaatimuksetkin olisi syytä ottaa huomioon reseptiivisen monikielisyyden edellytyksiä punnittaessa ja parannettaessa. Riskisanojen vaarallisuutta on toki aina pidetty esillä, mutta niiden haittavaikutuksen minimoinniksi voisi entisestään korostaa ympäröivän kokonaisuuden merkitystä: jos tekstin koherenttius olennaisesti kärsii petollisen ystävän aikaansaamasta uudesta temaattisesta käänteestä, on syytä miettiä vaihtoehtoisia ratkaisuja.

On selviö, että muihinkin kuin sukukieliin tutustuttaessa irrallisen sanaston lisäksi voidaan opettaa strategioita, joiden avulla tekstiyhteydestä on pääteltävissä tuntemattomien sanojen tarkoitteita. Merkitysoletusten tekeminen edellyttää kyseisen vieraan kielen jonkinasteista hallintaa: ympäröivän tekstin muista elementeistä riittävän määrän on oltava tuttuja. Toisen kielen omaksumisen ja opettamisen yhteydessä sanojen myötäesiintymiin ja niiden hyödyntämiseen onkin jo paneuduttu (ks. esim. Bonk 2000; Lewis 2000). Esitellessään tehokkaita oppimisstrategioita Kristiansen (1998: 25-31, 85-87, 203-205) korostaa sekä semanttisten hierarkioiden että skeemojen ja niihin liittyvien skriptien (toiminnallisten mallien ja vakiintuneiden repliikkien) merkitystä arkipäivän keskustelujen tulkinnassa.

Myös opetettaessa suomea toisena tai vieraana kielenä ajatus sanojen välisestä potentiaalisesta linkkiytymisestä on otettu huomioon. Esimerkiksi oppikirjassa Suomen mestari I (Gehring \& Heinzmann 2010: 
120) luetellaan vastakohtapareja, ja teoksessa Finskan. Lättare än du tror listataan semanttisia kenttiä niihin kuuluvine käsitteineen (Höglander \& Vehkanen 2001: 158-184). Samantapaisia ratkaisuja on viro toisena kielenä -oppikirjoissakin.

Onneksi uusissa monikielisissä verkkosanakirjoissa on tilaa merkitysvastineiden lisäksi niiden käyttöä havainnollistaville esimerkeille. Kotuksen Suomi-viro-suursanakirjassa on paitsi hakusana viime $\mathbf{1}$ 'möödunud, eelmine, läinud' myös fraseologisia yksiköitä kuten viime kerralla 'eelmisel korral', hän turvautui lääkäriin vasta viime hädässä 'ta pöördus arsti poole alles viimases hädas' ja viime kädessä 'kõige viimaks'.

Tämänhetkisessä vilkastuneen maahanmuuton aiheuttamassa tilanteessa oman kielen opetuksen tarve uusille tulokkaille on moniaalla lisääntynyt nopeasti. Vaihtoehtoisesti yritetään tulla toimeen jollain välittävällä, ehkä molempien osapuolien vain auttavasti hallitsemalla kielellä. Siksi olisi tärkeää ottaa käyttöön kaikki sellainen tieto, joka helpottaisi keskinäistä vuorovaikutusta, vaikka vierasta kieltä osattaisiin vain vähän. Taito hyödyntää vaikkapa semanttisten kytkösten ennakoitavuutta saattaa toimia ymmärtämisstrategiana. Sukukielten puhujilla on tietysti etua myös joidenkin yksittäisten sanojen samankaltaisuudesta, mutta merkityspäättelyn tukena kaikista vaihtoehtoisista, universaalisti jaetuista keinoista on hyötyä onnistuneen käännöksen löytämisessä.

\section{Kiitokset}

Suurkiitokset Annekatrin Kaivapalulle, Maria-Magdalena Jürvetsonille ja Jaan Õispuulle, jotka auttoivat aineiston hankinnassa, ja Hannu Remekselle, joka aina yhtä auliisti antaa apuaan viroa koskevien ongelmien ratkaisussa. Kiitokset myös nimettömille arvioijille, joiden kommenteista oli paljon hyötyä artikkelin viimeistelyssä.

\section{Lähteet}

Alvre, Paul, Raul Vodja 1995. Pulma poikineen. Virolais-suomalainen vertailusanakirja. Helsinki: WSOY.

Bonk, William 2000. Testing ESL Learners' Knowledge of Collocations. Illinois: Clearinghouse. 
Brown, Gillian, George Yule 1983. Discourse Analysis. Cambridge: Cambridge University Press. http://dx.doi.org/10.1017/CBO9780511805226

Collins, Alan M., R. Michael Quillian 1972. Experiments on semantic memory and language comprehension. - Lee W. Gregg (Ed.), Cognition in Learning and Memory. New York: Wiley 117-137.

Enkvist, Nils Erik 1975. Tekstilingvistiikan peruskäsitteitä ['Principles of Text Linguistics']. Helsinki: Gaudeamus.

Firth, John Rupert [1968] 1957. A synopsis of linguistic theory, 1930-55. - Frank Robert Palmer (Ed.), Selected Papers of J. R. Firth 1952-59. London: Longman, 168-205.

Gehring, Sonja, Sanni Heinzmann 2010. Suomen mestari 1. Suomen kielen oppikirja aikuisille. Helsinki: Finn Lectura.

Halliday, Michael A. K., Ruqaiya Hasan 1976. Cohesion in English. London: Longman.

Hoey, Michael 2005. Lexical Priming. A New Theory of Words and Language. London: Routledge.

Hoey, Michael 2007. Lexical priming and literary creativity. - Michael Hoey, Michaela Mahlberg, Michael Stubbs, Wolfgang Teubert (Eds.), Text, Discourse and Corpora. Theory and Analysis. London: Continuum, 7-29.

Hufeisen, Britta, Nicole Marx 2007. How can DaFnE and EuroComGerm contribute to the concept of receptive multilingualism. - Jan D. ten Thije, Ludger Zeevaert (Eds.), Receptive Multilingualism. Linguistic Analyses, Language Policies and Dialectic Concepts. Amsterdam-Philadelphia: John Benjamins, 307-321.

Höglander, Sari, Marjut Vehkanen 2001. Finskan. Lättare än du tror. Helsinki: Edita.

Jantunen, Jarmo 2009: "Minulla on aivan paljon rahaa” - Fraseologiset yksiköt suomen kielen opetuksessa. - Virittäjä 113, 356-381.

Kaivapalu, Annekatrin 2005. Lähdekieli kielenoppimisen apuna ['Contribution L1 to Foreign Language Acquisition']. Jyväskylä Studies in Humanities 44. Jyväskylä: Jyväskylän yliopisto.

Kaivapalu, Annekatrin, Pirkko Muikku-Werner 2010. Reseptiivinen monikielisyys: miten suomenkielinen oppija ymmärtää viroa äidinkielensä pohjalta? ['Receptive multilingualism: How Finnish as a first language helps learners to understand Estonian?'] - Lähivõrdlusi. Lähivertailuja 20, 68-97. http:// dx.doi.org/10.5128/LV20.03

Kristiansen, Irene 1998. Tehokkaita oppimisstrategioita. Helsinki: WSOY. 
Larjavaara, Matti 2007. Pragmasemantiikka. Helsinki: Suomalaisen Kirjallisuuden Seura.

Laalo, Klaus 1992. Huvitav lugu - kiinnostava juttu. Suomen ja viron välinen sanaston riskiryhmä ja sen tausta. Suomi 164. Helsinki: Suomalaisen Kirjallisuuden Seura.

Lewis, Michael (Ed.). 2000. Teaching Collocation: Further Developments in the Lexical Approach. Hove: Language Teaching Publications.

McNamara, Timothy P. 2005. Semantic Priming. Perspectives from Memory and Word Recognition. New York: Psychology Press. http://dx.doi. org/10.4324/9780203338001

Minsky, Marvin 1975. A framework for representing knowledge. - Patrick Winston (Ed.), The Psychology of Computer Vision. New York: MacGraw-Hill, 211-277.

Muikku-Werner, Pirkko 2013. Vironkielisen tekstin ymmärtäminen suomen kielen pohjalta ['Understanding Estonian texts on a Finnish language base']. - Lähivõrdlusi. Lähivertailuja 23, 210-237. http://dx.doi. org/10.5128/LV23.09

Muikku-Werner, Pirkko 2014. Co-text and receptive multilingualism - Finnish students comprehending. - Journal of Estonian and Finno-Ugric Linguistics 5 (3), 99-113.

Muikku-Werner, Pirkko 2015. Tekstin semanttiset sidokset ja lähisukukielen ymmärrettävyys ['Semantic cohesion and the intelligibility of closely related language']. - Lähivõrdlusi. Lähivertailuja 25, 191-216. http://dx.doi. org/10.5128/LV25.08

Muikku-Werner, Pirkko, Maria Heinonen 2012. Lumesadu - 'tarina' vai 'lumikasa' vai ei kumpikaan? Suomalaiset lukiolaiset viron sanoja tunnistamassa ['Lumesadu" - 'tarina' or 'lumikasa' or something completely different? How Finnish senior high school students try to recognise Estonian words']. - Lähivõrdlusi. Lähivertailuja 22, 157-187. http://dx.doi. org/10.5128/LV22.06

Neely, James H. 1991. Semantic priming effects in visual word recognition: A selective review of current findings and theories. - Derek Besner, Glyn W. Humphreys (Eds.), Basic Progresses in Reading and Visual Word Recognition. Hillsdale, NJ: Erlbaum, 264-333.

Paajanen, Ilona 2012. "Kitsas tee" - 'laiha tee' vai 'kapea tie'? Suomen kielen opiskelijat ja viron ymmärtäminen testissä [“'Tee on kitsas” - is 'tea bitter' or are you 'penny-pinching'? Finnish students comprehending Estonian']. Julkaisematon pro gradu -tutkielma. Itä-Suomen yliopisto. 
Pajanen, Ilona, Pirkko Muikku-Werner 2012. “Tee on kitsas” - onko 'tee kitkerää’ vai oletteko 'te saita'? Suomalaiset opiskelijat viroa ymmärtämässä [“Tee on kitsas" - is 'tea bitter' or are you 'penny-pinching'? Finnish students comprehending Estonian']. - Lähivõrdlusi. Lähivertailuja 22, 219-258. http://dx.doi.org/10.5128/LV22.08

Pace-Sigge, Michael 2013. The concept of lexical priming in the context of language use. - ICAME Journal 37, 149-173.

Sinclair, John 1996. The search for units of meaning. - Textus IX, 75-106.

Singer, Murray 2007. Inference processing in discourse comprehension. M. Gareth Gaskell (Ed.), The Oxford Handbook of Psycholinguistics. Oxford: University Press, 343-359.

van Bezooijen, Renée, Charlotte Gooskens 2007. Interlingual text comprehension. Linguistic and extralinguistic determinants. - Jan D. ten Thije, Ludger Zeevaert (Eds.), Receptive Multilingualism. Linguistic Analyses, Language Policies and Didactic Concepts. Amsterdam-Philadelphia: John Benjamins Publishing Company, 249-264.

\section{Pirkko Muikku-Werner}

Itä-Suomen yliopiston humanistinen osasto, suomen kieli ja kulttuuritieteet

PL 111

FI-80101 Joensuu, Finland

pirkko.muikku-werner@uef.fi 


\title{
Multidimensional similarity: Estonians and comprehension of Finnish text
}

\author{
PIRKKO MUIKKU-WERNER \\ University of Eastern Finland
}

Previous studies have proven that Finns reading an Estonian text use many different strategies to find the meanings of cognate words. In this article, the factors affecting the Estonians' ability to understand Finnish are described. It is well known that external similarity promotes intelligibility, but on the other hand, "false friends" can cause misinterpretations if the context does not prevent them. On the other hand, certain concepts connected on the basis of different semantic relationships can contribute to the emergence of correct translation. When dealing with phraseological units the first word primes the occurrence of the second word (target). It is assumed that in the foreign language text the prime, if recognizable in L1, helps to infer the target.

In order to test these assumptions, Estonian informants had to translate a short Finnish text into Estonian and explain their choices of translation equivalents for certain words. Most test participants are aged over 20, some of them were 1st year high school students. None of them had had formal instruction in Finnish.

The results show that, on the one hand, the relation between hyponyms and hypernyms and, on the other hand, the chain of cause and consequence facilitates the finding of the meaning of unknown word. However, the translation is mostly based on external similarity of unconnected lexical items which can result in success or failure. The informants justify their proposals for translation equivalents with that kind of similarity but they also rely on the structure of semantic fields and conceptions of coherent texts. The qualities of semantic relations are not bound to the affinity of Estonian and Finnish but to some universal "regularities", another sort of similarity.

Keywords: receptive multilingualism; context; semantic priming; phraselogical unit; Finnish; Estonian 